\title{
$B c l-x$ Is Required for Proper Development of the Mouse Substantia Nigra
}

\author{
Joseph M. Savitt, ${ }^{1,2}$ Susie S. Jang, ${ }^{1}$ Weitong Mu, ${ }^{5}$ Valina L. Dawson,,${ }^{1,2,3,4}$ and Ted M. Dawson ${ }^{1,2,3}$ \\ ${ }^{1}$ Institute for Cell Engineering and Departments of ${ }^{2}$ Neurology, ${ }^{3}$ Neuroscience, ${ }^{4}$ Physiology, and ${ }^{5}$ Internal Medicine, Division of Gastroenterology, Johns \\ Hopkins University School of Medicine, Baltimore, Maryland 21205
}

Recent findings have uncovered a role for the $B c l-x$ gene in the survival of dopaminergic neurons. The exact nature of this role has been difficult to examine because of the embryonic lethality of $B c l-x$ gene disruption in mouse models. Here we report the generation of catecholaminergic cell-specific conditional $B c l$ - $x$ gene knock-out mice using Cre-lox recombination technology. First we produced transgenic mice that express Cre recombinase from an exogenous rat tyrosine hydroxylase promoter ( $T H$-Cre mice). These mice were crossed to $Z / A P$ and $Z / E G$ reporter mouse strains to verify catecholaminergic (TH-positive) cell-specific Cre expression. The TH-Cre mice then were mated to mice possessing the $B c l-x$ gene flanked by loxP sites, thereby producing offspring with $B c l-x$ deletion limited to catecholaminergic cells. The resulting mice are viable but have one-third fewer catecholaminergic neurons than do control animals. They demonstrate a deficiency in striatal dopamine and also tend to be smaller and have decreased brain mass when compared with controls. Surprisingly, surviving neurons were found that lacked Bcl-x immunoreactivity, thereby demonstrating that this gene is dispensable for the ongoing survival of a subpopulation of catecholaminergic cells.

Key words: Parkinson; Bcl-x; catecholamine; substantia nigra; dopamine; tyrosine hydroxylase

\section{Introduction}

Parkinson's disease (PD) is a relatively common neurodegenerative disorder with $\sim 70,000$ new cases diagnosed in the United States annually (Mayeux, 2003). Underlying the symptoms of PD is the degeneration of several neuronal subtypes, including the conspicuous loss of dopamine-containing neurons in the substantia nigra pars compacta (SNPc) (Lang and Lozano, 1998). Loss of $60-80 \%$ of the these cells and the resulting decrease in striatal dopamine correlate with symptom onset (Pakkenberg et al., 1991; Subramanian, 2001; Isacson, 2002). In addition to the SNPc, other catecholaminergic regions, including the locus ceruleus (LC), olfactory nuclei, sympathetic ganglia, and adrenal medulla show pathology in PD (Pierce and Bari, 2001; Braak et al., 2003; Micieli et al., 2003). Many of the cells in these regions express tyrosine hydroxylase $(\mathrm{TH})$, the rate-limiting enzyme in catecholamine biosynthesis.

The factors responsible for PD pathology are mostly unknown. Recent data have implicated mitochondrial dysfunction, oxidative stress, and proteasomal dysfunction in the death of

\footnotetext{
Received Feb. 24, 2005; revised May 31, 2005; accepted May 31, 2005.

This work was supported by a clinician scientist award from the Passano Foundation (J.M.S.), the Lee Martin Trust, the Sylvia Nachlas Trust, the Morris K. Udall Parkinson's Disease Research Center, and National Institutes of Health-National Institute of Neurological Disorders and Stroke Grant NS 38377. T.M.D. is the Leonard and Madlyn Abramson professor in neurodegenerative diseases. We thank Dr. Jin Son for providing the $9.0 \mathrm{~kb}$ rat TH promoter, Dr. S. O'Gorman for providing the Cre construct, Drs. E. Rucker and K. Wagner for providing the BCl-x floxed mice, and Drs. C. Lobe and A. Nagy for providing the valuable Z/AP and Z/EG reporter mice to the research community.

Correspondence should be addressed to Dr. Ted M. Dawson, Institute for Cell Engineering, Johns Hopkins University School of Medicine, 733 North Broadway, Broadway Research Building, Suite 731, Baltimore, MD 21205. E-mail: tdawson@jhmi.edu.

D0I:10.1523/JNEUROSCI.0760-05.2005

Copyright $\odot 2005$ Society for Neuroscience $\quad$ 0270-6474/05/256721-08\$15.00/0
}

nigral neurons (Dawson and Dawson, 2003). Attempts by the cell to counteract these stressors may involve the survival factor Bcl- $\mathrm{x}_{\mathrm{L}}$ (Hartmann et al., 2002). Specifically, this protein is upregulated in the surviving dopaminergic neurons of $\mathrm{PD}$ patients (Hartmann et al., 2002), in neuroblastoma cells exposed to the dopaminergic neurotoxin 1-methyl-4-phenylpyridinium $(\mathrm{MPP}+)$ (Veech et al., 2000), and in cybrid cell cultures containing mitochondrial complex I deficiency (Veech et al., 2000). In addition, $\mathrm{Bcl}-\mathrm{x}_{\mathrm{L}}$ overexpression in embryonic stem cells promotes dopaminergic differentiation and enhances MPP + resistance (Shim et al., 2004). Bcl- $\mathrm{x}_{\mathrm{L}}$ is a product of the $\mathrm{Bcl}-2$ family gene $B c l-x$. The gene is expressed in many regions throughout the developing and adult animal, including the CNS, where it prevents neuronal cell death (Gonzalez-Garcia et al., 1995; Mizuguchi et al., 1996). Indeed, $B c l$-x gene inactivation leads to extensive cell death in the hematopoietic system and CNS, resulting in embryonic lethality (Motoyama et al., 1995).

To better study the role of $B c l-x$ in dopaminergic cell function, we set out to interrupt this gene specifically in catecholaminergic neurons. Our hypothesis was that this would avoid the hematopoietic failure and embryonic lethality seen in the genome-wide knock-out and therefore provide an opportunity to study the role of $B c l-x$ in catecholaminergic cells beyond the embryonic period. Furthermore, in light of increasing evidence that dopaminergic neurons rely heavily on $B c l-x$ function for survival, we postulated that dopaminergic cells lacking this gene would not survive. Such a finding would verify that $B c l-x$ is required for dopaminergic cell survival in vivo and in an environment of normal $B c l-x$ expression.

To accomplish the targeted deletion of $B c l-x$, we generated mice that express Cre recombinase in TH-containing cells and 
crossed them to mice homozygous for the loxP-flanked $B c l-x$ gene (Rucker et al., 2000). The resulting animals demonstrate deficiencies in the catecholaminergic system and also show that $B c l-x$ is dispensable for continued survival of this cell population even at advanced ages. These mice provide the first opportunity to examine the consequences of $B c l-x$ deletion on postnatal neuronal survival in vivo.

\section{Materials and Methods}

Animals. All mice were housed and treated in strict accordance with the National Institutes of Health Guide for the Care and Use of Laboratory Animals. They were kept in a pathogen-free facility and exposed to a $12 \mathrm{~h}$ light/dark cycle with food and water provided ad libitum.

Transgenic TH-Cre mice were generated by microinjection of fertilized B6/SJLF2 oocytes at the pronuclear stage with a linearized fragment of the pTH-Cre vector. This vector was created using a pSP73 (Promega, Madison, WI) backbone. The TH promoter consisting of the SalI-EcoRI fragment of the pTH9000 plasmid (Min et al., 1994) was placed upstream from a cassette containing the Cre-coding sequence flanked upstream by a synthetic intron initially derived from the $5^{\prime}$-untranslated sequence of the adenovirus-major late region (Huang and Gorman, 1990) and 3' by the simian virus 40 (SV40) late region polyadenylation site [all derived from the pOG231 vector (O'Gorman et al., 1997)]. An $11 \mathrm{~kb}$ SalI-NotI fragment was isolated using the GELase preparation reagent (Epicenter, Madison, WI), resuspended in $10 \mathrm{~mm}$ Tris, $\mathrm{pH}$ 7.5, and 0.1 mM EDTA, and provided to the Johns Hopkins Transgenic Core Facility for microinjection. Five lines of mice containing the TH-Cre transgene ( $\mathrm{TH}$-Cre 1-TH-Cre 5) were identified by PCR amplification of tail DNA using the primers 5' ${ }^{\prime}$-AAA TGT TGC TGG ATA GTT TTT ACT GC-3' and 5'GGA AGG TGT CCA ATT TAC TGA CCG TA-3'. The expected 300 bp fragment was visualized by standard agarose gel electrophoresis.

Mice possessing the loxP-flanked $B c l-x$ gene were generously provided by Dr. Edmund Rucker (University of Missouri, Columbia, MO) (Rucker et al., 2000). The presence of the floxed Bcl-x gene was determined by PCR around the $5^{\prime}$ loxP site using the primers $5^{\prime}$-CGG TTG CCT AGC AAC GGG GC- $3^{\prime}$ and $5^{\prime}$-CTC CCA CAG TGG AGA CCT CG-3', giving a wild-type band of $200 \mathrm{bp}$ and a floxed gene product of $300 \mathrm{bp}$, or around the $3^{\prime}$ site using primers 5' -TCA GAA GCC GCA ATA TCC CC- $3^{\prime}$ and 5'-GCC ACC TCA TCA GTC GGG-3', yielding a wildtype product of $150 \mathrm{bp}$ and a floxed gene product of $\sim 200 \mathrm{bp}$. These $\mathrm{fl} / \mathrm{fl}$ $B c l-x$ mice have been used successfully to examine the role of $B c l-x$ in a variety of cell types, including those in the liver, ovary, and mammary gland, as well as in erythroid and dendritic cells (Rucker et al., 2000; Wagner et al., 2000; Walton et al., 2001; Riedlinger et al., 2002; Hon et al., 2004; Takehara et al., 2004).

The $f l / f l B c l-x$ mice were crossed to TH-Cre mice (lines 1 and 3), and the offspring were bred to homozygosity at the loxP-flanked $B c l$ - $x$ locus. This enabled the Cre recombinase to inactivate the $B c l-x$ gene specifically in cells in which the TH promoter is active (i.e., catecholaminergic cells). Cre-mediated excision of $B c l-x$ genomic sequences was detected by PCR on DNA isolated from ventral midbrain tissue of adult animals using the forward primers $5^{\prime}$-CGG TTG CCT AGC AAC GGG GC-3' and 5' -AAT GGC CAG TAC TAG TGA ACC-3' and the reverse primer 5' -TCA GAA GCC GCA ATA TCC CC- $3^{\prime}$ as described previously (Wagner et al., 2000).

The Z/AP mouse line (Lobe et al., 1999) was provided by the Johns Hopkins Transgenic Core Facility, and the $Z / E G$ mouse was purchased from The Jackson Laboratory (Bar Harbor, ME). These strains were genotyped by staining tail tissue for $\beta$-galactosidase activity. Tail samples were immersed in lacZ staining solution containing $2 \mathrm{~mm}$ magnesium chloride, $0.01 \%$ sodium deoxycholate, $0.02 \% \mathrm{NP}-40,100 \mathrm{~mm}$ sodium phosphate, $\mathrm{pH} 7.3,1 \mathrm{mg} / \mathrm{ml} 5$-bromo-4-chloro-3-indolyl- $\beta$ D-galactopyranoside, $6 \mathrm{~mm}$ potassium ferrocyanide, and $5 \mathrm{~mm}$ potassium ferricyanide and were incubated for $5 \mathrm{~min}$ at $37^{\circ} \mathrm{C}$. Positive samples were identified by a blue reaction product.

For the isolation of tissues for immunohistochemistry and enzyme histochemistry, animals were anesthetized with a lethal dose of pentobarbital $(100 \mathrm{mg} / \mathrm{kg})$ and perfused through the left ventricle with $50 \mathrm{ml}$ of ice-cold PBS followed by $75 \mathrm{ml}$ of ice-cold $4 \%$ paraformaldehyde in PBS. Relevant tissues were dissected and postfixed in $4 \%$ paraformaldehyde and PBS overnight at $4^{\circ} \mathrm{C}$ and cryoprotected for $36-48 \mathrm{~h}$ in $30 \%$ sucrose and PBS at $4^{\circ} \mathrm{C}$.

Enzyme histochemistry. Staining for human placental alkaline phosphatase activity was performed as described previously, with minor modifications (Lobe et al., 1999). Tissue was processed as $30 \mu \mathrm{m}$ cryostat sections (retina, adrenal gland, and $1 \mathrm{~d}$ pup tissue) or $40 \mu \mathrm{m}$ microtome sections (brain) cut from frozen paraformaldehyde-fixed tissue. Endogenous alkaline phosphatase activity was quenched by incubation at $70^{\circ} \mathrm{C}$ for $30 \mathrm{~min}$ in PBS. The samples were allowed to cool for $2 \mathrm{~min}$ and washed with PBS at room temperature. Sections were transferred to a solution containing $100 \mathrm{~mm}$ Tris- $\mathrm{HCl}, \mathrm{pH} 9.5,100 \mathrm{~mm} \mathrm{NaCl}$, and $10 \mathrm{~mm}$ $\mathrm{MgCl}_{2}$ for $10 \mathrm{~min}$ and then transferred to staining solution consisting of $100 \mathrm{~mm}$ Tris- $\mathrm{HCl}, \mathrm{pH}$ 9.5, $100 \mathrm{~mm} \mathrm{NaCl}, 50 \mathrm{~mm} \mathrm{MgCl}_{2}, 0.01 \%$ sodium deoxycholate, $0.02 \% \mathrm{NP}-40,340 \mu \mathrm{g} / \mathrm{ml}$ nitroblue tetrazolium, and 175 $\mu \mathrm{g} / \mathrm{ml}$ 5-bromo-4-chloro-3-indolyl-phosphate (Roche Molecular Biochemicals, Indianapolis, IN) for 15-30 min at room temperature in the dark. Sections were washed in PBS and allowed to air dry before dehydration and mounting in distrene plasticizer xylene (Sigma, St. Louis, MO).

Immunohistochemistry. Forty micrometer sections were cut on a sliding microtome (Microm, Kalamazoo, MI) and collected free-floating in PBS. Sections were permeabilized and blocked in PBS containing $0.2 \%$ Triton X-100 and 10\% normal goat serum at room temperature for $1 \mathrm{~h}$. Sections then were incubated in 1:2000 rabbit anti-TH antibody (Novus Biologicals, Littleton, CO) overnight at $4^{\circ} \mathrm{C}$ and washed with PBS containing $0.1 \%$ Triton $\mathrm{X}-100$. Next, sections were incubated for $2 \mathrm{~h}$ in 1:500 biotin-labeled $\mathrm{F}\left(\mathrm{ab}^{\prime}\right)_{2}$ fragment goat anti-rabbit antibody (Jackson Im-

A

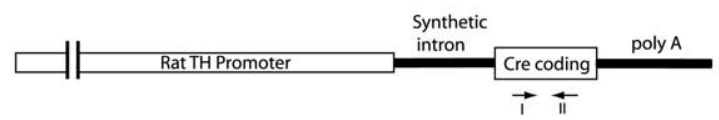

B

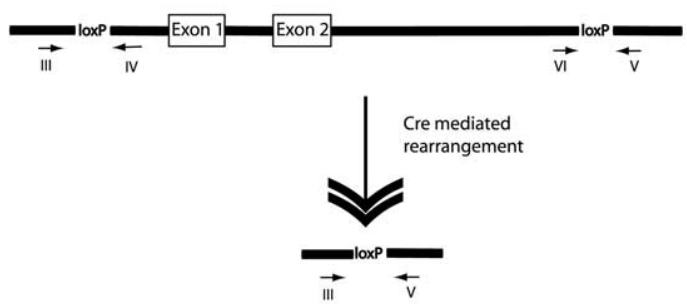

C

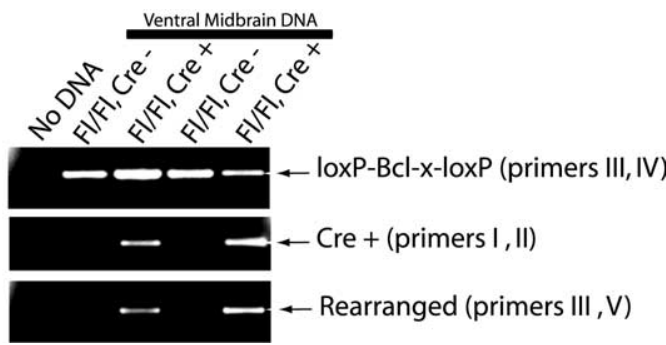

Figure 1. Targeting the $B C l-x$ gene in TH + cells. $A, A$ TH-Cre construct possessing a $9.0 \mathrm{~kb}$ fragment of the rat TH promoter, synthetic intron, Cre CDNA, and an SV40 polyadenylation sequence. Numbered arrows represent primers used to screen for the Cre-coding sequence. $\boldsymbol{B}, \mathrm{A}$ map of the $B C l-x$ locus containing a floxed version of the gene and the predicted product of Cre-mediated recombination, including the elimination of a region of the $5^{\prime}$-untranslated sequence, exons 1 and 2, and intervening DNA. Numbered arrows represent PCR primers. C, A montage of ethidium bromide-stained $2.0 \%$ agarose gel of $P C R$ products amplified from ventral midbrain DNA of indicated mouse strains. PCR using primers III and V demonstrates selective deletion of DNA between loxP sites in the presence of Cre recombinase in vivo. Each lane represents midbrain DNA samples isolated from an individual mouse of the indicated genotype. 


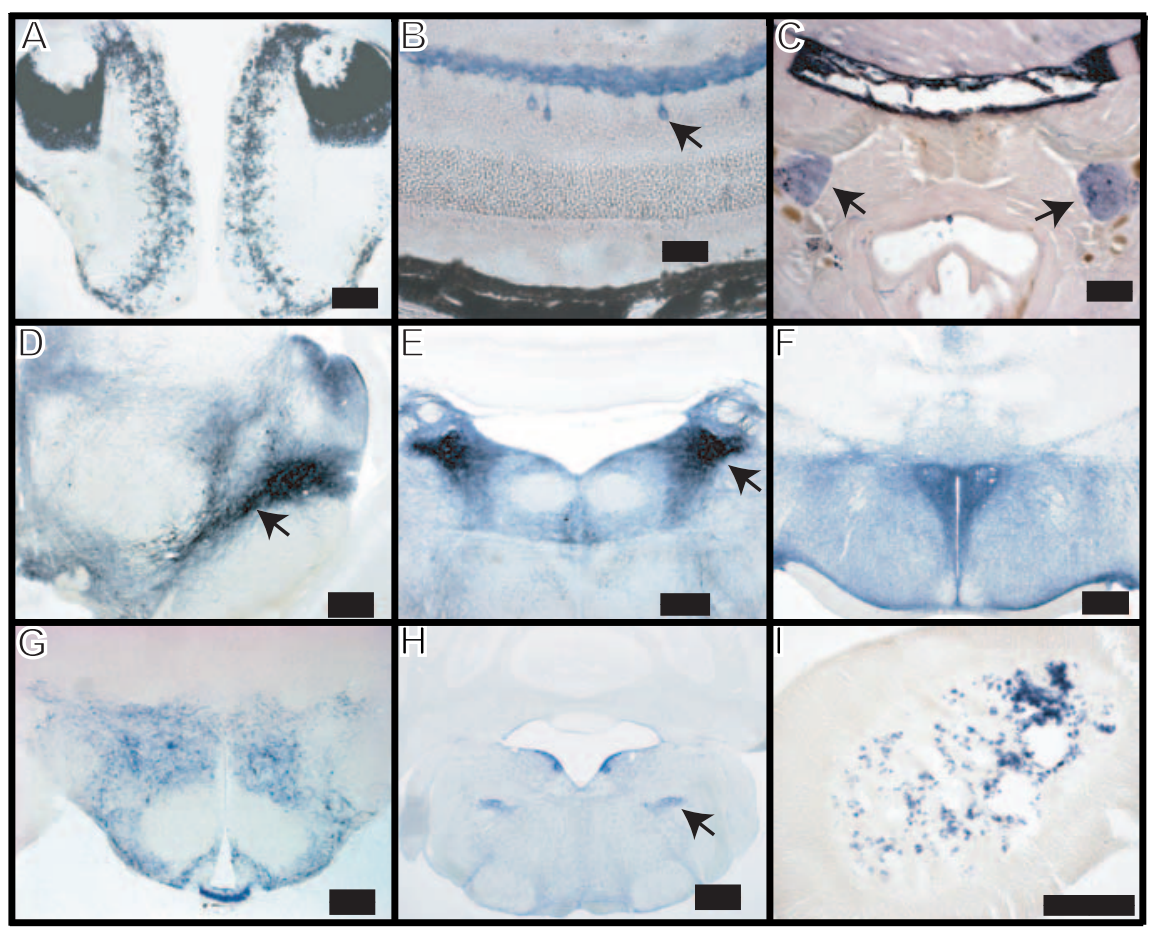

Figure 2. Regional localization of Cre recombinase activity. TH-Cre and Z/AP double transgenic mouse tissue was stained for human placental alkaline phosphatase activity (blue), indicating the presence of Cre recombinase activity. Staining is seen in the periglomerular layer of the olfactory bulb and the accessory olfactory bulb $(\boldsymbol{A})$, amacrine cells (arrow) and dendritic plexus of the retina $(\boldsymbol{B})$, superior cervical ganglia ( $\boldsymbol{C}$, arrows), substantia nigra (arrow) and ventral tegmental area of the midbrain $(\boldsymbol{D})$, locus ceruleus $(\boldsymbol{E}$, arrow), periventricular and paraventricular nuclei of the hypothalamus $(\boldsymbol{F})$, hypothalamic area, including the arcuate nucleus, median eminence, and zona incerta $(\boldsymbol{G})$, dorsal medullary adrenergic cells $(\boldsymbol{H}$, arrow), and adrenal medulla $(\boldsymbol{I})$. All tissues are from adult mice, except for $C$, in which tissue was removed from $24 \mathrm{~h}$ paraformaldehyde immersion-fixed 1-d-old pups. Scale bars: $B, 25 \mu \mathrm{m} ; A, C-I, 200 \mu \mathrm{m}$.

munoResearch, West Grove, PA) in PBS, $0.2 \%$ Triton X-100, and 2\% goat serum, washed, and visualized by incubation in biotin-streptavidin-HRP (Vector Laboratories, Burlingame, CA), followed by incubation with 3,3'-diaminobenzidine per the manufacturer's instructions (Sigma). Sections were mounted on glass slides, dehydrated, and coverslipped for visualization. Sections for double-immunofluorescent labeling were processed similarly using 1:500 rabbit anti-Bcl-x (PharMingen, San Diego, CA) and 1:2000 mouse anti-TH (Immunostar, Hudson, WI) as primary antibodies and cyanine $3(\mathrm{Cy} 3)$-conjugated goat anti-mouse $\operatorname{IgG} \mathrm{F}\left(\mathrm{ab}^{\prime}\right)_{2}$-specific and Cy2-conjugated goat anti-rabbit IgG $\mathrm{F}\left(\mathrm{ab}^{\prime}\right)_{2}$ specific as secondary antibodies at a 1:500 dilution (Jackson ImmunoResearch). Sections were mounted in Vectashield (Vector Laboratories) and kept in the dark until visualized by confocal microscopy using a Zeiss (Thornwood, NY) LSM-510 microscope. Slides processed for stereology were prepared as above, and TH-positive SNPc and locus ceruleus neurons were counted using nonbiased stereologic methods with the optical fractionator as described previously (West, 1993; Mandir et al., 1999) and using software provided by MicroBrightField (Williston, VT). Selected sections were Nissl-counterstained and counted as described above.

HPLC. HPLC with electrochemical detection was used to measure striatal levels of dopamine, 3,4-dihydroxyphenylacetic acid, and homovanillic acid. Conditional $B c l-x$ knock-out mice and age- and gendermatched controls were killed by decapitation, the brains were quickly removed, and striata were dissected. Samples were sonicated in $50 \mathrm{vol}$ of $0.1 \mathrm{M}$ perchloric acid containing $25 \mu \mathrm{g} / \mathrm{ml}$ dihydroxybenzylamine (Sigma) as an internal standard. After centrifugation $(15,000 \times g, 10 \mathrm{~min}$, $\left.4^{\circ} \mathrm{C}\right), 20 \mu \mathrm{l}$ of supernatant was injected onto a Brownlee C-18 reverse phase Spheri $5 \mathrm{RP}-184.6 \mathrm{~mm} \times 25 \mathrm{~cm}$ column. The mobile phase consisted of $0.15 \mathrm{M}$ chloroacetic acid, $0.1 \mathrm{~mm}$ EDTA, and $0.86 \mathrm{M}$ sodium octyl

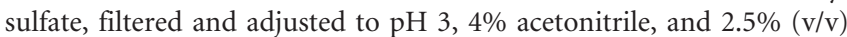
tetrahydrofuran. The flow rate was kept at $1.5 \mathrm{ml} / \mathrm{min}$. Peaks were detected by an Amperometric LC-4C detector (Bioanalytical System, West
Lafayette, IN), and the working electrode was kept at $0.7 \mathrm{~V}$. Data were collected and processed on a Star Chromatography 5.52 workstation (Varian, Palo Alto, CA).

Rotorod. A cohort of adult male mice was initially trained on an accelerating rotorod apparatus (Rotamex; Columbus Instruments, Columbus, $\mathrm{OH})$. Animals first were placed on the $3 \mathrm{~cm}$ rod and subjected to multiple trials until time spent on the rod reached a plateau $(\sim 16$ trials). Trials began with the rod at $4 \mathrm{rpm}$ and accelerated to $50 \mathrm{rpm}$ over $5 \mathrm{~min}$. Agematched animals were tested during similar times of day by an observer blinded to subject genotype and always in parallel with littermate controls. Once plateau values had been reached, each group of animals was subjected to four independent trials, and their time on the rod was averaged.

Statistics. Throughout the experiments, the investigators were blinded to the genotype of the mice. All values are expressed as mean \pm SEM. Differences among means were analyzed by using standard Student's $t$ tests or two-tailed ANOVA followed by the Bonferroni posttest as appropriate. In all analyses, the null hypothesis was rejected at the $p=0.05$ level. All statistical analyses were performed using GraphPad (San Diego, CA) InStat and Prism software.

\section{Results}

Tissue-specific expression of Cre recombinase in catecholaminergic cells Microinjection of recombinant DNA containing the Cre recombinase coding sequence downstream of the well characterized $9.0 \mathrm{~kb}$ fragment of the rat $\mathrm{TH}$ promoter (Fig. $1 A$ ) yielded five independent lines of mice containing the Cre transgene (named TH-Cre 1-TH-Cre 5). Creexpressing mice are fertile, are indistinguishable from their wildtype littermates, and have continued to yield offspring that express the transgene years after their original development. Breeding outcomes suggest that the transgene is present on autosomal chromosomes in all lines except line four, in which the transgene appears to be X-linked (data not shown). Tissuespecific expression of Cre recombinase was demonstrated by crossing each $T H$-Cre mouse line to $Z / A P$ and $Z / E G$ reporter mice (Lobe et al., 1999; Novak et al., 2000). The $Z / A P$ mouse expresses the lac $Z$ gene during embryonic and adult stages and in nearly all cells except erythrocytes, chondrocytes, and adipocytes. On Cre-mediated rearrangement, the lac $Z$ gene is inactivated and human placental alkaline phosphatase (hPLAP) is activated and expressed at high levels in those cells expressing Cre. The hPLAP enzyme is easily localized by histochemical methods. Z/EG mice function in a similar way, but with activation of the green fluorescent protein (GFP) gene after Cre-mediated recombination. There are no obvious differences between lines $1-5$ in the pattern of hPLAP or GFP expression with the exception of minimally altered cell type expression in the retina (data not shown). As expected, Cre recombinase activity is found in those mouse cells containing an active TH promoter, i.e., cathecholaminergic cells (Figs. 2, 3). Specifically, dopaminergic cell populations, including those in the retina (amacrine cells), substantia nigra, retrorubral field, ventral tegmental area, zona incerta, hypothalamus, and olfactory bulb, stain for Cre recombinase activity, as do the nor- 


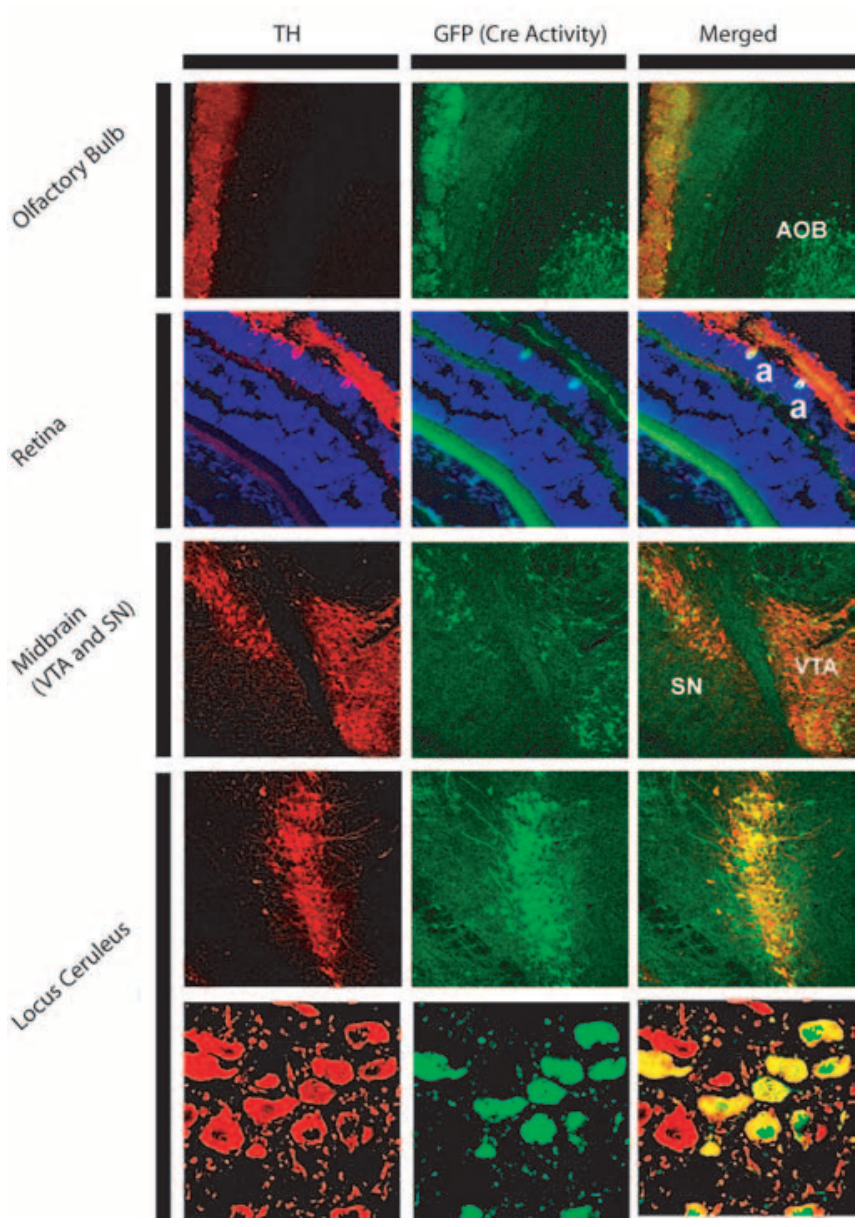

Figure 3. Cellular localization of Cre recombinase activity. Indicated mouse tissue was visualized by confocal microscopy demonstrating the presence of TH immunoreactivity (Cy3; red) and Cre recombinase activity (GFP; green). Colocalization is seen in the glomerular layer of the olfactory bulb, the amacrine cells of the retina (a), the substantia nigra (SN), the ventral tegmental area (VTA), and the locus ceruleus. AOB, Accessory olfactory bulb. Magnification: top four rows, $40 \times$; bottom row, $100 \times$.

adrenergic cells of the locus ceruleus, sympathetic ganglia, and medulla, as well as the adrenergic cells in the adrenal medulla and lower brainstem. In addition, Cre reporter activity is present in many of the projection areas of these neuronal populations such as the striatum, amygdala, and nucleus accumbens, likely because of filling of axonal processes with hPLAP or GFP (data not shown). Several other areas that are not typically thought to have active TH expression, including the lateral septal nucleus, accessory olfactory bulb, suparafascicular thalamus, and pretectal area, also stain for Cre activity, possibly as a result of TH promoter activity in precursor cell populations or ectopic expression from the exogenous $\mathrm{TH}$ promoter. Indeed, ectopic expression driven by the exogenous TH promoter has been described previously (Min et al., 1994; Gelman et al., 2003). Interestingly, some cells closely clustered around and within TH-positive nuclei (locus ceruleus and substantia nigra) demonstrate Cre activity, although they do not stain for TH protein (Fig. 3). Conversely, Cre-mediated recombination is not detected in 100\% of the targeted cell population; rather, a mosaic of Cre activity is noted in TH-positive neurons (Fig. 3).

Generation of $B c l-x$ gene deletion in catecholaminergic cells Conditional $\mathrm{Bcl}-x$ gene disruption in catecholaminergic cells was accomplished by crossing $\mathrm{TH}$-Cre mice to mice possessing a
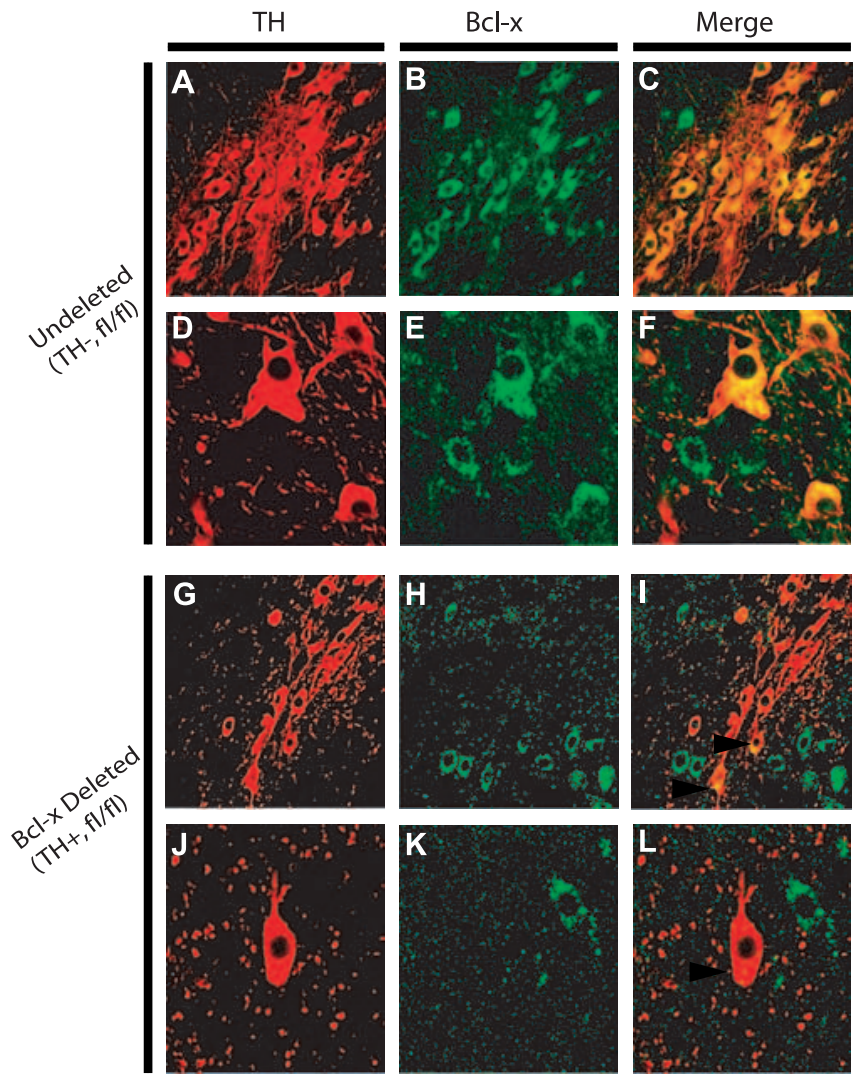

Figure 4. $\quad B C l-x$ immunoreactivity is lost in a subset of TH-positive neurons of conditional knock-out mice. Tissue sections from the substantia nigra were taken from adult $T H$-Cre negative, $f / / f l B C l-x$ (undeleted) $(\boldsymbol{A}-\boldsymbol{F})$ and $T H$-Cre positive, $f / / f l B C l-x(B C l-x$-deleted) $(\mathbf{G}-\boldsymbol{L})$ mice, stained for the presence of $\mathrm{TH}$ (red) and $\mathrm{BCl}-\mathrm{x}$ (green) and visualized by confocal microscopy. Some TH-positive cells in the $T H$-cre, fl/fl BCl-x substantia nigra continue to express $\mathrm{BCl}-\mathrm{x}(\boldsymbol{I}$, arrowheads), whereas others clearly do not (L, arrowhead). Magnification: $A-C, G-I, 40 \times$; $D-F, J-L, 100 \times$.

floxed $B c l-x$ gene. Genotyping of the offspring was conducted by PCR using the strategy shown (Fig. 1). Gene disruption is specifically demonstrated by PCR amplification of DNA isolated from the ventral midbrain of mice containing the TH-Cre transgene and two copies (homozygous) of the floxed $B c l-x$ gene (Fig. 1C). No rearranged product is detected in the absence of the Cre transgene. To verify the loss of Bcl-x expression, mouse brain tissue was double-labeled with antibodies to $\mathrm{TH}$ and $\mathrm{Bcl}-\mathrm{x}$. Visualization with fluorescent secondary antibodies and subsequent confocal microscopy demonstrates the loss of Bcl-x protein in a subset of TH-positive cells (Fig. 4). Many cells, however, stain for both proteins, suggesting that $\mathrm{Bcl}-x$ deletion does not occur in all $\mathrm{TH}$-positive cells. Those TH-positive cells lacking Bcl-x demonstrate $\mathrm{TH}$ immunoreactivity and morphology that are indistinguishable from those containing Bcl-x (Fig. 4).

Animals with the $\mathrm{Bcl}-x$ gene disrupted in $\mathrm{TH}$-positive neurons $(\mathrm{TH}-\mathrm{Cre}, \mathrm{fl} / \mathrm{fl} \mathrm{Bcl}-\mathrm{x})$ appear as healthy and active as $\mathrm{TH}$-Crenegative littermate controls, and expected genotypic ratios are obtained, suggesting no early survival disadvantage from $B c l-x$ deletion (data not shown). In individual litters, $T H$-Cre, $f l / f l B c l-x$ mice are reduced in weight by $18-30 \%$ relative to their control (Cre-negative) littermates (Fig. 5). The overall health, coordination, balance, and activity of the control and $B c l-x$ conditionally deleted mice were assayed using an accelerating rotorod protocol. $B c l$ - $x$-deleted animals are able to stay on the rod significantly longer $(127 \pm 13$ vs $81 \pm 9.4 \mathrm{~s} ; p=0.007)$ and at higher velocities 

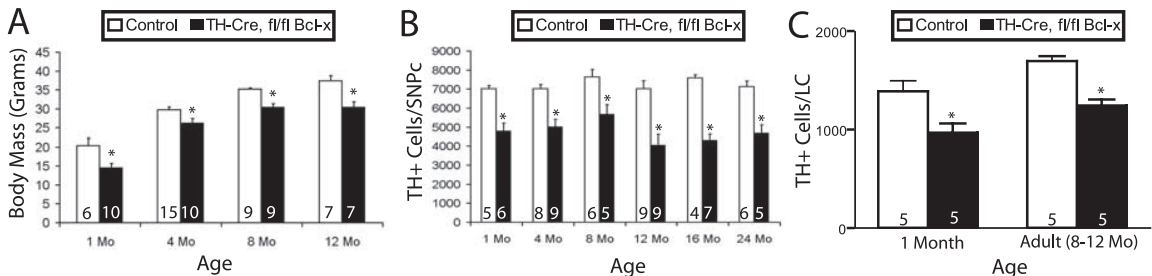

Figure 5. Differences between control and $B C l-x$ conditional knock-outs. $A$, Catecholaminergic cell-specific $B C l-x$ conditional knock-out animals show decreased body mass. $B, C$, Catecholaminergic cell-specific $B C l-x$ conditional knock-out animals possess fewer TH-containing neurons in the SNPc and LC. ${ }^{*} p<0.05$, statistical significance versus age-matched controls using ANOVA. Values inside bars indicate the numbers of measurements, and cell counts represent total numbers of cells per bilateral nuclei.

when compared with control animals, suggesting no major motor system defects in these animals.

Conditional $B c l-x$ knock-outs have reduced striatal dopamine and fewer TH-positive SNPc and locus ceruleus neurons

$\mathrm{TH}$ immunoreactivity is decreased in the midbrain of $\mathrm{TH}$-Cre, $\mathrm{fl} / \mathrm{fl} \mathrm{Bcl}-\mathrm{x}$ mice compared with controls (Fig. 6). This effect was quantified by stereological counting of SNPc cells, which shows reduced numbers of $\mathrm{TH}$-immunoreactive cells at all ages tested (Fig. 5). The magnitude of cell loss does not change appreciably with age and ranges from 25 to 33\%. This is reflected in fewer Nissl-staining neurons in the SNPc as well, verifying that loss of $\mathrm{TH}$ staining is the result of fewer neurons, not merely the downregulation of TH protein in individual cells (data not shown). A similar finding was seen in the locus ceruleus, where TH-positive cell numbers are reduced by $31 \%$ in 1 -month-old TH-Cre, $f l / f l$ $B c l-x$ mice and by $27 \%$ in adults (8-12 months of age) relative to age- and gender-matched controls (Fig. 5). Interestingly, confocal double-labeling experiments show occasional surviving $\mathrm{TH}$ positive cells that do not stain for Bcl-x in the brains of TH-Cre, $f l / f l B c l-x$ mice, whereas no such cells are seen in controls (Fig. 4). These cells are relatively rare, however, and most cells in the TH-Cre, fl/fl Bcl- $x$ mice do show Bcl-x and TH colocalization. HPLC analysis of $\mathrm{TH}$-Cre, $\mathrm{fl} / \mathrm{fl} \mathrm{Bcl}-\mathrm{x}$ striatum shows a statistically significant reduction in dopamine and its metabolites when compared with controls (dopamine, $23.3 \pm 1.0 \mathrm{vs} 18.7 \pm 1.2 \mathrm{ng} / \mathrm{mg}$ of tissue; 3,4-dihydroxyphenylacetic acid, $1.3 \pm 0.07$ vs $1.1 \pm 0.08$ $\mathrm{ng} / \mathrm{mg}$ of tissue; and homovanillic acid, $0.50 \pm 0.08$ vs $0.32 \pm$ $0.11 \mathrm{ng} / \mathrm{mg}$ of tissue; $p<0.04$ ). Ratios of metabolites to dopamine levels are similar in controls and $\mathrm{TH}-\mathrm{Cre}, \mathrm{fl} / \mathrm{fl} \mathrm{Bcl}-\mathrm{x}$ mice, suggesting no alteration in dopamine metabolism in the surviving cells (data not shown). Overall brain weight also is reduced $(508 \pm 24$ vs $571 \pm 8 \mathrm{mg} ; p<0.03)$ in adult $\mathrm{TH}-\mathrm{Cre}, \mathrm{fl} / \mathrm{flBcl}-\mathrm{x}$ mice compared with age- and gender-matched controls.

\section{Discussion}

\section{Characterization and utility of $\mathrm{TH}$-Cre mice}

In $\mathrm{PD}$, dopaminergic cells of the SNPc and noradrenergic cells of the LC as well as other catecholaminergic cells are among those most affected (Halliday et al., 1990; Zarow et al., 2003). Thus, we hypothesized that targeting catecholaminergic cells via genetic manipulation would provide a valuable tool for the study of PD. We used the well characterized $9.0 \mathrm{~kb}$ rat $\mathrm{TH}$ promoter to drive expression of Cre recombinase in transgenic mice (Min et al., 1994, 1996). The resulting Cre expression in catecholaminergic cells provides a simple way to selectively alter genes in these cells. Using $Z / A P$ and $Z / E G$ indicator mouse lines, we have shown specific expression of Cre activity in catecholaminergic cells. This along with the generation of multiple mouse lines showing similar Cre localization proves that the $\mathrm{TH}$ promoter is driving Cre expression. Also, mice described previously and produced in a similar manner demonstrate Cre localization that parallels that seen here (Gelman et al., 2003).

Despite the presence of $\mathrm{TH}$ in most Cre-expressing cells, there are some cells that demonstrated Cre activity but lacked detectable TH. The explanation for this discrepancy likely varies according to cell type. For example, cells in the accessory olfactory nucleus possess an active $\mathrm{TH}$ promoter but do not translate appreciable amounts of protein (Min et al., 1994). Such posttranscription control does not exist for Cre mRNA and explains the presence of Cre activity in these cells. Other explanations for the presence of Cre activity in $\mathrm{TH}$-negative cells include ectopic $\mathrm{TH}$ promoter activity and the activation of the promoter in less mature cells that either never produced $\mathrm{TH}$ protein or subsequently lost this ability. In the latter case, expression of Cre at any time during development would lead to persistent reporter gene $(Z / A P$ or $Z / E G)$ expression. Such cell marking could be useful for tracking cells derived from precursors that possess an active TH promoter. Conversely, Cre activity was not seen in all TH-positive cells, suggesting genetic mosaicism, a common finding in transgenic models (Nagy, 2000; Tronche et al., 2002).

\section{Requirement for $B c l-x$ in the SNPc}

$B c l-x$ is a $B c l-2$ gene family member and is spliced into five isoforms (Yang et al., 2002), including two major isoforms: the antiapoptotic $\mathrm{Bcl}-\mathrm{x}_{\mathrm{L}}$ and the proapoptotic $\mathrm{Bcl}-\mathrm{x}_{\mathrm{S}}$ (Boise et al., 1993). Most nervous system effects are mediated by Bcl- $\mathrm{x}_{\mathrm{L}}$ because $\mathrm{Bcl}-\mathrm{x}_{\mathrm{S}}$ is expressed at low or undetectable levels in the brain (Boise et al., 1993; Gonzalez-Garcia et al., 1995; Krajewska et al., 2002). Murine Bcl-x gene interruption results in embryonic lethality likely from hematopoeitic failure (Motoyama et al., 1995; Shindler et al., 1997). These animals exhibit cell death in hematopoetic areas of the liver and in regions of the CNS. The prenatal lethality of $B c l-x$ deletion prompted the production of several lines of Cre-mediated, conditional $B c l-x$ knock-out mice (Rucker et al., 2000; Wagner et al., 2000; Hon et al., 2004; Takehara et al., 2004). Similarly, we have generated mice that lack $B c l-x$ gene products specifically in catecholaminergic cells. These animals have approximately one-third fewer SNPc dopaminergic neurons compared with littermate controls. To determine whether this effect is specific for dopaminergic cells, TH-positive neurons within the noradrenergic LC, another region susceptible to cell loss in PD, also were assayed. The magnitude of cell loss seen here is similar to that in the SNPc, suggesting that $B c l-x$ is required for the proper development of catecholaminergic cells whether they are dopaminergic or noradrenergic. The majority of the remaining cells contain both $\mathrm{Bcl}-\mathrm{x}$ and $\mathrm{TH}$. These cells result from failure of $B c l-x$ deletion, their numbers possibly augmented by a survival advantage conferred on precursor cells lacking $B c l-x$ recombination. The absence of widespread TH-positive neurons without $\mathrm{Bcl}-\mathrm{x}$ immunoreactivity in adult animals suggests that in most TH-expressing cells, $B c l-x$ gene deletion is incompatible with cell survival. This effect likely results from a loss of the antiapoptotic activity of the $\mathrm{Bcl}-\mathrm{x}_{\mathrm{L}}$ isoform. Indeed, $\mathrm{Bcl}-\mathrm{x}_{\mathrm{L}}$ plays an important role in the development and survival of neurons. This is suggested by the expression profile of the protein, which peaks between embryonic day 13 and postnatal day 5 (Krajewska et al., 2002), and by the cell death that occurs in postmitotic but imma- 


\section{Control Bcl-x Deleted}

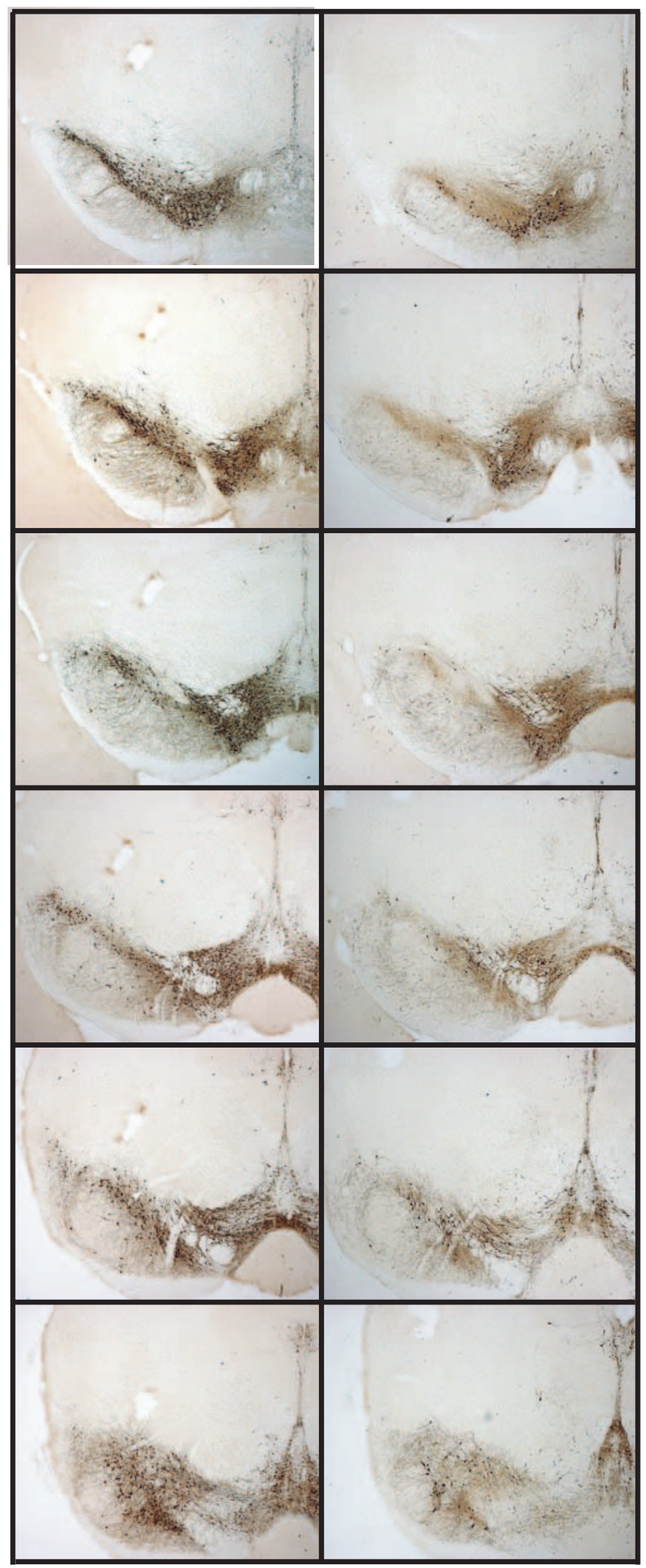

Figure 6. Comparison of TH immunoreactivity in the midbrain of $T H$-Cre-negative, $f / f l B C l-x$ (control) and $T H$-Cre-positive, $f l / f l(B C l-x$-deleted) mice. Every fourth consecutive $40 \mu \mathrm{m}$ section was stained in the region of the substantia nigra and ventral tegmental area, and similar sections were matched side by side. Staining reactions were performed on adult mouse tissue for identical periods and qualitatively demonstrate fewer TH-positive cells in the BCl-x-deleted mice. Magnification, $5 \times$. ture neurons when the protein is deficient (Motoyama et al., 1995; Roth et al., 1996, 2000). This neuronal cell death is thought to be cell autonomous because it can be demonstrated in telencephalic cultures of neurons derived from $B c l$ - $x$-deficient embryos (Roth et al., 1996) and can be reversed by Bax gene deletion, although $B c l-x / B a x$ double-knock-out animals still die prenatally (Shindler et al., 1997). Our data lend strong support for the endogenous neuronal requirement of $B c l-x$ during development.

Our study also supports data demonstrating the antiapoptotic effect of Bcl- $\mathrm{x}_{\mathrm{L}}$ in dopaminergic neurons. This includes previous studies showing that the dopaminergic cell line MN9D is rescued from staurosporine-mediated cell death by overexpression of $\mathrm{Bcl}-\mathrm{x}_{\mathrm{L}}$ (Kim et al., 1999), and differentiated PC12 cells overexpressing Bcl- $\mathrm{x}_{\mathrm{L}}$ are more resistant to serum withdrawal (Blomer et al., 1998). Recently, Bcl- $\mathrm{X}_{\mathrm{L}}$ was used to increase the generation of TH-positive neurons from embryonic stem (ES) cells (Liste et al., 2004; Shim et al., 2004). Indeed, as ES cells are coaxed into a dopaminergic phenotype, levels of endogenous $B c l-x_{L}$ increase, whereas ES cells expressing exogenous $B \mathrm{Bcl}-\mathrm{x}_{\mathrm{L}}$ demonstrate $\mathrm{MPP}+$ resistance and show increased neurite outgrowth and functional recovery in animal PD models (Shim et al., 2004). Last, studies on human neurospheres have demonstrated that $\mathrm{TH}$ overexpression is toxic to these cells and that $\mathrm{Bcl}-\mathrm{x}_{\mathrm{L}}$ can partially ameliorate this toxicity (Liste et al., 2004).

Some neurons in our study avoid the lethal effects of $B c l-x$ deletion. The presence of such cells is demonstrated by their lack of Bcl-x immunoreactivity and by the ability to detect the appropriate genetic rearrangement in tissue from animals containing the TH-Cre transgene and two copies of the floxed $B c l-x$ allele. This verifies that the appropriate Cre-mediated gene inactivation has taken place in these animals and shows that, despite a loss of $\mathrm{Bcl}-\mathrm{x}$ protein, catecholaminergic neurons can survive. This suggests a window of vulnerability in TH neuron development. The TH promoter is activated as early as embryonic day 9, and its expression continues into adulthood (Son et al., 1996). Some cells may escape Cre-mediated $B c l-x$ deletion early in development only to have the gene inactivated at later stages when the requirement for $B c l-x$ has passed. Similar findings are seen in ovarian and mammary gland tissue, where the requirement for $B c l-x$ is developmental stage-specific (Walton et al., 2001; Riedlinger et al., 2002). The role of $B c l-x$ in maintaining postnatal neuronal survival has been inferred by its continued expression into adulthood (Frankowski et al., 1995; Gonzalez-Garcia et al., 1995; Yachnis et al., 1998) and the fact that adult neurons from mice overexpressing $\mathrm{Bcl}-\mathrm{x}$ are resistant to cell death stimuli such as hypoxia and axotomy (Parsadanian et al., 1998). Our findings suggest that the requirement for $B c l-x$ is not absolute, and the presence of $\mathrm{Bcl}-\mathrm{x}_{\mathrm{L}}$ in adult brains may serve functions other than maintaining cell survival under baseline conditions. The lack of progressive cell death in our conditional knock-out animals suggests that even advanced age fails to trigger increased loss of dopaminergic neurons.

Curiously the $B c l-x$ conditional knock-out animals have reduced brain and body mass as well as enhanced rotorod performance. Decreased weight may be the result of effects on the hypothalamus, where Cre expression and thus $B c l-x$ deletion occur. Also, a change in growth rate may affect brain size, as would the depletion of neurons. Many factors influence rotorod behavior, and further study will be required to determine the reason behind the improved performance. Possible candidate factors include strain differences, body size, and visual impairment, all of which have been correlated to rotorod score (McFadyen et al., 2003). In addition, a recent study has shown a negative correlation between 
mouse body weight and rotorod fall latency, perhaps making animal size the most likely factor explaining our animals' enhanced performance (Lalonde et al., 2005).

This study has implications regarding our understanding of the pathology of $\mathrm{PD}$. It is known that $\mathrm{Bcl}-\mathrm{x}_{\mathrm{L}}$ is present in human adult substantia nigral cells, and its nigral cell mRNA expression is increased in the brains of PD patients with the caveat that those neurons containing Lewy bodies have reduced levels (Hartmann et al., 2002). In addition, cybrid cell culture models of PD find that cells containing mitochondria derived from PD patients demonstrated increased levels of $\mathrm{Bcl}-\mathrm{x}_{\mathrm{L}}$ compared with controls (Veech et al., 2000). The present study shows that $B c l-x$ function is dispensable in mature dopaminergic neurons and implies that loss of $\mathrm{Bcl}$ - $x$ function is an unlikely primary mechanism for the loss of these cells in PD. Confirmation of the importance of cellautonomous expression of $B c l-x$ for the proper development of the SNPc does support the use of this protein in developing methods to generate dopaminergic cells from precursor populations such as embryonic and neural stem cells.

\section{References}

Blomer U, Kafri T, Randolph-Moore L, Verma IM, Gage FH (1998) Bcl-xL protects adult septal cholinergic neurons from axotomized cell death. Proc Natl Acad Sci USA 95:2603-2608.

Boise LH, Gonzalez-Garcia M, Postema CE, Ding L, Lindsten T, Turka LA, Mao X, Nunez G, Thompson CB (1993) bcl-x, a bcl-2-related gene that functions as a dominant regulator of apoptotic cell death. Cell 74:597-608.

Braak H, Del Tredici K, Rub U, de Vos RA, Jansen Steur EN, Braak E (2003) Staging of brain pathology related to sporadic Parkinson's disease. Neurobiol Aging 24:197-211.

Dawson TM, Dawson VL (2003) Molecular pathways of neurodegeneration in Parkinson's disease. Science 302:819-822.

Frankowski H, Missotten M, Fernandez PA, Martinou I, Michel P, Sadoul R, Martinou JC (1995) Function and expression of the Bcl-x gene in the developing and adult nervous system. NeuroReport 6:1917-1921.

Gelman DM, Noain D, Avale ME, Otero V, Low MJ, Rubinstein M (2003) Transgenic mice engineered to target $\mathrm{Cre} /$ loxP-mediated DNA recombination into catecholaminergic neurons. Genesis 36:196-202.

Gonzalez-Garcia M, Garcia I, Ding L, O'Shea S, Boise LH, Thompson CB, Nunez G (1995) bcl-x is expressed in embryonic and postnatal neural tissues and functions to prevent neuronal cell death. Proc Natl Acad Sci USA 92:4304-4308.

Halliday GM, Li YW, Blumbergs PC, Joh TH, Cotton RG, Howe PR, Blessing WW, Geffen LB (1990) Neuropathology of immunohistochemically identified brainstem neurons in Parkinson's disease. Ann Neurol 27:373-385.

Hartmann A, Mouatt-Prigent A, Vila M, Abbas N, Perier C, Faucheux BA, Vyas S, Hirsch EC (2002) Increased expression and redistribution of the antiapoptotic molecule Bcl-xL in Parkinson's disease. Neurobiol Dis 10:28-32.

Hon H, Rucker III EB, Hennighausen L, Jacob J (2004) bcl-xL is critical for dendritic cell survival in vivo. J Immunol 173:4425-4432.

Huang MT, Gorman CM (1990) Intervening sequences increase efficiency of RNA 3' processing and accumulation of cytoplasmic RNA. Nucleic Acids Res 18:937-947.

Isacson O (2002) Models of repair mechanisms for future treatment modalities of Parkinson's disease. Brain Res Bull 57:839-846.

Kim JE, Oh JH, Choi WS, Chang II, Sohn S, Krajewski S, Reed JC, O’Malley KL, Oh YJ (1999) Sequential cleavage of poly(ADP-ribose)polymerase and appearance of a small Bax-immunoreactive protein are blocked by $\mathrm{Bcl}-\mathrm{X}(\mathrm{L})$ and caspase inhibitors during staurosporine-induced dopaminergic neuronal apoptosis. J Neurochem 72:2456-2463.

Krajewska M, Mai JK, Zapata JM, Ashwell KW, Schendel SL, Reed JC, Krajewski S (2002) Dynamics of expression of apoptosis-regulatory proteins Bid, Bcl-2, Bcl-X, Bax and Bak during development of murine nervous system. Cell Death Differ 9:145-157.

Lalonde R, Dumont M, Staufenbiel M, Strazielle C (2005) Neurobehavioral characterization of APP23 transgenic mice with the SHIRPA primary screen. Behav Brain Res 157:91-98.
Lang AE, Lozano AM (1998) Parkinson's disease. First of two parts. N Engl J Med 339:1044-1053.

Liste I, Garcia-Garcia E, Martinez-Serrano A (2004) The generation of dopaminergic neurons by human neural stem cells is enhanced by Bcl-XL, both in vitro and in vivo. J Neurosci 24:10786-10795.

Lobe CG, Koop KE, Kreppner W, Lomeli H, Gertsenstein M, Nagy A (1999) $\mathrm{Z} / \mathrm{AP}$, a double reporter for cre-mediated recombination. Dev Biol 208:281-292.

Mandir AS, Przedborski S, Jackson-Lewis V, Wang ZQ, Simbulan-Rosenthal CM, Smulson ME, Hoffman BE, Guastella DB, Dawson VL, Dawson TM (1999) Poly(ADP-ribose) polymerase activation mediates 1-methyl-4phenyl-1,2,3,6-tetrahydropyridine (MPTP)-induced parkinsonism. Proc Natl Acad Sci USA 96:5774-5779.

Mayeux R (2003) Epidemiology of neurodegeneration. Annu Rev Neurosci 26:81-104

McFadyen MP, Kusek G, Bolivar VJ, Flaherty L (2003) Differences among eight inbred strains of mice in motor ability and motor learning on a rotorod. Genes Brain Behav 2:214-219.

Micieli G, Tosi P, Marcheselli S, Cavallini A (2003) Autonomic dysfunction in Parkinson's disease. Neurol Sci 24 [Suppl 1]:S32-S34.

Min N, Joh TH, Kim KS, Peng C, Son JH (1994) 5' upstream DNA sequence of the rat tyrosine hydroxylase gene directs high-level and tissue-specific expression to catecholaminergic neurons in the central nervous system of transgenic mice. Brain Res Mol Brain Res 27:281-289.

Min N, Joh TH, Corp ES, Baker H, Cubells JF, Son JH (1996) A transgenic mouse model to study transsynaptic regulation of tyrosine hydroxylase gene expression. J Neurochem 67:11-18.

Mizuguchi M, Sohma O, Takashima S, Ikeda K, Yamada M, Shiraiwa N, Ohta S (1996) Immunochemical and immunohistochemical localization of Bcl-x protein in the rat central nervous system. Brain Res 712:281-286.

Motoyama N, Wang F, Roth KA, Sawa H, Nakayama K, Negishi I, Senju S, Zhang Q, Fujii S, Loh DY (1995) Massive cell death of immature hematopoietic cells and neurons in Bcl-x-deficient mice. Science 267:1506-1510.

Nagy A (2000) Cre recombinase: the universal reagent for genome tailoring. Genesis 26:99-109.

Novak A, Guo C, Yang W, Nagy A, Lobe CG (2000) Z/EG, a double reporter mouse line that expresses enhanced green fluorescent protein upon Cremediated excision. Genesis 28:147-155.

O'Gorman S, Dagenais NA, Qian M, Marchuk Y (1997) Protamine-Cre recombinase transgenes efficiently recombine target sequences in the male germ line of mice, but not in embryonic stem cells. Proc Natl Acad Sci USA 94:14602-14607.

Pakkenberg B, Moller A, Gundersen HJ, Mouritzen Dam A, Pakkenberg H (1991) The absolute number of nerve cells in substantia nigra in normal subjects and in patients with Parkinson's disease estimated with an unbiased stereological method. J Neurol Neurosurg Psychiatry 54:30-33.

Parsadanian AS, Cheng Y, Keller-Peck CR, Holtzman DM, Snider WD (1998) Bcl-xL is an antiapoptotic regulator for postnatal CNS neurons. J Neurosci 18:1009-1019.

Pierce RC, Bari AA (2001) The role of neurotrophic factors in psychostimulant-induced behavioral and neuronal plasticity. Rev Neurosci 12:95-110.

Riedlinger G, Okagaki R, Wagner KU, Rucker III EB, Oka T, Miyoshi K, Flaws JA, Hennighausen L (2002) Bcl-x is not required for maintenance of follicles and corpus luteum in the postnatal mouse ovary. Biol Reprod 66:438-444.

Roth KA, Motoyama N, Loh DY (1996) Apoptosis of bcl-x-deficient telencephalic cells in vitro. J Neurosci 16:1753-1758.

Roth KA, Kuan C, Haydar TF, D'Sa-Eipper C, Shindler KS, Zheng TS, Kuida K, Flavell RA, Rakic P (2000) Epistatic and independent functions of caspase- 3 and $\mathrm{Bcl}-\mathrm{X}(\mathrm{L})$ in developmental programmed cell death. Proc Natl Acad Sci USA 97:466-471.

Rucker III EB, Dierisseau P, Wagner KU, Garrett L, Wynshaw-Boris A, Flaws JA, Hennighausen L (2000) Bcl-x and Bax regulate mouse primordial germ cell survival and apoptosis during embryogenesis. Mol Endocrinol 14:1038-1052.

Shim JW, Koh HC, Chang MY, Roh E, Choi CY, Oh YJ, Son H, Lee YS, Studer L, Lee SH (2004) Enhanced in vitro midbrain dopamine neuron differentiation, dopaminergic function, neurite outgrowth, and 1-methyl-4phenylpyridium resistance in mouse embryonic stem cells overexpressing Bcl-XL. J Neurosci 24:843-852. 
Shindler KS, Latham CB, Roth KA (1997) Bax deficiency prevents the increased cell death of immature neurons in bcl-x-deficient mice. J Neurosci 17:3112-3119.

Son JH, Min N, Joh TH (1996) Early ontogeny of catecholaminergic cell lineage in brain and peripheral neurons monitored by tyrosine hydroxylase-lacZ transgene. Brain Res Mol Brain Res 36:300-308.

Subramanian T (2001) Cell transplantation for the treatment of Parkinson's disease. Semin Neurol 21:103-115.

Takehara T, Tatsumi T, Suzuki T, Rucker III EB, Hennighausen L, Jinushi M, Miyagi T, Kanazawa Y, Hayashi N (2004) Hepatocyte-specific disruption of $\mathrm{Bcl}-\mathrm{xL}$ leads to continuous hepatocyte apoptosis and liver fibrotic responses. Gastroenterology 127:1189-1197.

Tronche F, Casanova E, Turiault M, Sahly I, Kellendonk C (2002) When reverse genetics meets physiology: the use of site-specific recombinases in mice. FEBS Lett 529:116-121.

Veech GA, Dennis J, Keeney PM, Fall CP, Swerdlow RH, Parker Jr WD, Bennett Jr JP (2000) Disrupted mitochondrial electron transport function increases expression of anti-apoptotic bcl-2 and bcl-X(L) proteins in SH-SY5Y neuroblastoma and in Parkinson disease cybrid cells through oxidative stress. J Neurosci Res 61:693-700.

Wagner KU, Claudio E, Rucker III EB, Riedlinger G, Broussard C,
Schwartzberg PL, Siebenlist U, Hennighausen L (2000) Conditional deletion of the Bcl-x gene from erythroid cells results in hemolytic anemia and profound splenomegaly. Development 127:4949-4958.

Walton KD, Wagner KU, Rucker III EB, Shillingford JM, Miyoshi K, Hennighausen L (2001) Conditional deletion of the bcl-x gene from mouse mammary epithelium results in accelerated apoptosis during involution but does not compromise cell function during lactation. Mech Dev 109:281-293.

West MJ (1993) New stereological methods for counting neurons. Neurobiol Aging 14:275-285.

Yachnis AT, Giovanini MA, Eskin TA, Reier PJ, Anderson DK (1998) Developmental patterns of BCL-2 and BCL-X polypeptide expression in the human spinal cord. Exp Neurol 150:82-97.

Yang XF, Ye Q, Press B, Han RZ, Bassing CH, Sleckman BP, Alt FW, Cantor $\mathrm{H}$ (2002) Analysis of the complex genomic structure of Bcl-x and its relationship to $\mathrm{Bcl}-\mathrm{x}$ (gamma) expression after $\mathrm{CD} 28$-dependent costimulation. Mol Immunol 39:45-55.

Zarow C, Lyness SA, Mortimer JA, Chui HC (2003) Neuronal loss is greater in the locus coeruleus than nucleus basalis and substantia nigra in Alzheimer and Parkinson diseases. Arch Neurol 60:337-341. 